\title{
Synthesis of novel 6-enaminopurines
}

\author{
M. Alice Carvalho, ${ }^{a}$ Magdi E. A. Zaki, ${ }^{a}$ Yolanda Álvares, ${ }^{a}$ M. Fernanda Proença*a and \\ Brian L. Booth ${ }^{b}$ \\ a Departamento de Química, Universidade do Minho, Campus de Gualtar, 4710-057, Braga, \\ Portugal.E-mail: fproenca@quimica.uminho.pt; Fax: +351 253 678983; Tel: +351 253604379 \\ ${ }^{b}$ Chemistry Department, University of Manchester Institute of Science and Technology, \\ Manchester, UK M60 1QD
}

Received 6th May 2004, Accepted 14th June 2004

First published as an Advance Article on the web 27th July 2004

Two different approaches have been used for the synthesis of 6-enaminopurines 6 from 5-amino-4-cyanoformimidoyl imidazoles $\mathbf{1}$. In the first approach imidazoles 1 were reacted with ethoxymethylenemalononitrile or ethoxymethylenecyanoacetate under mild experimental conditions and this led to 9-substituted-6-(1-amino-2,2-dicyanovinyl) purines 6a-f or 9-substituted-6-(1-amino-2-cyano-2-methoxycarbonylvinyl) purines $\mathbf{6 g}-\mathbf{k}$. These reactions are postulated to occur through an imidazo-pyrrolidine intermediate 7 , which rapidly rearranges to the 6-enaminopurine 6.

In the second approach 6-methoxyformimidoyl purines $\mathbf{3}$, prepared in two efficient steps from 5-amino-4-cyanoformimidoyl imidazoles $\mathbf{1}$, were reacted with malononitrile and methylcyanoacetate with a mild acid catalysis (ammonium acetate or piperidinium acetate) to give 6-enaminopurines $\mathbf{6 a}, \mathbf{6 d}, \mathbf{6 f}, \mathbf{6 g}$ and $\mathbf{6 k}$ in very good yields. Only low yields were obtained for the 6-enaminopurine $\mathbf{6 j}$, as competing nucleophilic attack on C-8 of either $\mathbf{3 d}$ or $\mathbf{6 j}$ causes ring opening with formation of pyrimido-pyrimidines 11 and 10a respectively.

\section{Introduction}

The biological importance of the purine structure is evident from the countless derivatives that have been prepared and are active, especially as antiviral ${ }^{1,2}$ and antitumour ${ }^{1,3}$ agents. The substituent in the 6-position plays an important role in the potency and selectivity of the purine derivatives. As a result, great efforts have been directed to the synthesis and biological evaluation of a number of 6-substituted purines. These compounds are usually prepared from the appropriate 6-halogenopurine by halogen-displacement reactions, including the use of acid-catalyzed cross-coupling reactions. To our knowledge, however, only a few methods were reported for the introduction of an enamine moiety in the 6-position of the purine ring. The 6-(2'-aminomethylene) group is usually generated by catalytic hydrogenation of the 6-cyanomethylene substituent, which can be prepared in high yield by reaction of the sodium salt of an activated cyanomethylene such as malononitrile, ${ }^{4} \alpha$-cyanoacetamide ${ }^{5}$ and ethylcyanoacetate ${ }^{6}$ with 6 -halogenated or methylsulfonated purine derivatives. An earlier synthesis of a 6-(2'arylaminomethylene)purine uses 6-methylpurine as the starting material. The reaction with the Vilsmeyer reagent in the presence of aniline or substituted aniline, ultimately leads to the product. ${ }^{7}$

The present work describes the synthesis of 9-substituted-6-(1'aminomethylene)purines using two different but equally efficient approaches. To our knowledge, the preparation of these compounds has not been reported in the literature.

\section{Results and discussion}

The reaction of $N$-aryl-5-amino-4-cyanoformimidoyl imidazoles 1a-d with ethoxymethylenemalononitrile (1.5 equiv.) at room temperature, using acetonitrile or a combination of acetonitrile and DMF as solvent (Scheme 1) gave the 6-enaminopurines 6. These precipitate from the reaction mixture and can be isolated in high yields, as a pure product, after filtration. The reaction is usually fast ( $6 \mathrm{~h}$ at room temperature) except when the 1-(4-cyanophenyl)imidazole $1 \mathbf{d}$ is used as the starting material. In this case, the poor solubility of the imidazole in acetonitrile: DMF $(5: 2)$ leads to a much slower reaction (3 days at room temperature). A mechanism for this reaction (Scheme 2 ) is proposed on the basis of a ${ }^{1} \mathrm{H}$ NMR study on the evolution of imidazole 1c $\left(\mathrm{R}=4-\mathrm{FC}_{6} \mathrm{H}_{4}\right)$ in the presence of ethoxymethylenemalononitrile (3 equiv.) in a deuterated acetonitrile solution (Fig. 1). Only one intermediate species could be detected during a clean reaction leading to product $\mathbf{6 c}$. The concentration of this compound does not exceed $6 \%$ but its signals are clearly identifiable as structure 7 (Scheme 2) from a singlet at $\delta 7.27 \mathrm{ppm}$ integrating for one proton, indicative of an imidazole ring; a proton at $\delta 6.57 \mathrm{ppm}$ for a pyrrolidine substituent and a broad singlet at $\delta 6.07 \mathrm{ppm}(2 \mathrm{H})$ for an amino group in the 5-position of an imidazole ring. The reaction was monitored by measurement of the disappearance of the methyl signal of the OEt group in $\mathbf{5 a}(\delta 1.42 \mathrm{ppm})$ with the appearance of a similar signal at $\delta$ $1.24 \mathrm{ppm}$ for the intermediate 7 . The appearance of the final product 6c could not be measured directly as it precipitates from solution, but the formation of the ethanol by-product (Me signal at $\delta 1.17 \mathrm{ppm}$ ) could be measured. The results also indicate that the product is present in $50 \%$ yield after approximately $40 \mathrm{~min}$ at $20^{\circ} \mathrm{C}$.

The 6-enaminopurine $\mathbf{6 b}$ could also be prepared from amidine 9 (Scheme 3), the precursor of imidazole $\mathbf{1 b}$. These amidines promptly cyclize in the presence of $\mathrm{DBU},{ }^{8}$ using ethanol as solvent, and ethoxymethylenemalononitrile was added directly to the reaction mixture, avoiding the isolation step of $\mathbf{1 b}$. The product $\mathbf{6} \mathbf{b}$ precipitates from solution and was isolated in $91 \%$ yield.

When the $N$-aryl imidazoles 1a-d were combined with ethoxymethylenecyanoacetate (1.5 equiv.) a slower reaction occurred. The pure product was again isolated upon filtration of the reaction mixture, except when the aryl group is 4-cyanophenyl, where the low solubility of imidazole 1d in the solvent system (acetonitrile: DMF, $5: 3$ ) results in a prolonged reaction time ( 5 days at room temperature). The product $\mathbf{6 j}$ remains in solution and the work up procedure results in lower isolated yields of this compound.

The reaction between $N$-alkyl imidazole 1e and ethoxymethylenemalononitrile (1.2-1.5 equiv.) was only carried out in acetonitrile, and as both the reagents and product are very soluble in this solvent this caused difficulties in isolating the pure product from the reaction mixture resulting in the low isolated yield of purine 6 e $(29 \%)$.

The structure of the 6-enaminopurines $\mathbf{6}$ was assigned on the basis of elemental analysis and spectroscopic data. For purines $\mathbf{6 a}-\mathbf{f}$, the two cyano groups are usually present in the IR spectrum as two distinct and intense bands in the regions of $2215-2225 \mathrm{~cm}^{-1}$ and $2200-2210 \mathrm{~cm}^{-1}$. In the ${ }^{13} \mathrm{C}$ NMR spectrum, the signals for both cyano groups are also clearly identified around $\delta 115$ and $\delta 116 \mathrm{ppm}$. Another typical feature is the chemical shift of both carbon atoms of the alkene substituent in the 6-position of the purine ring. The carbon atom directly bonded to the amino group gives a signal around $\delta$ $165 \mathrm{ppm}$, while the adjacent carbon (bonded to the two cyano groups) leads to a small band (absent in the spectrum of $6 \mathbf{e}$ ) around $\delta$ $50 \mathrm{ppm}$. In the ${ }^{1} \mathrm{H}$ NMR spectrum, the amino group leads to two singlets around $\delta 9.10 \mathrm{ppm}$ and $\delta 9.40 \mathrm{ppm}$, each one integrating for one 


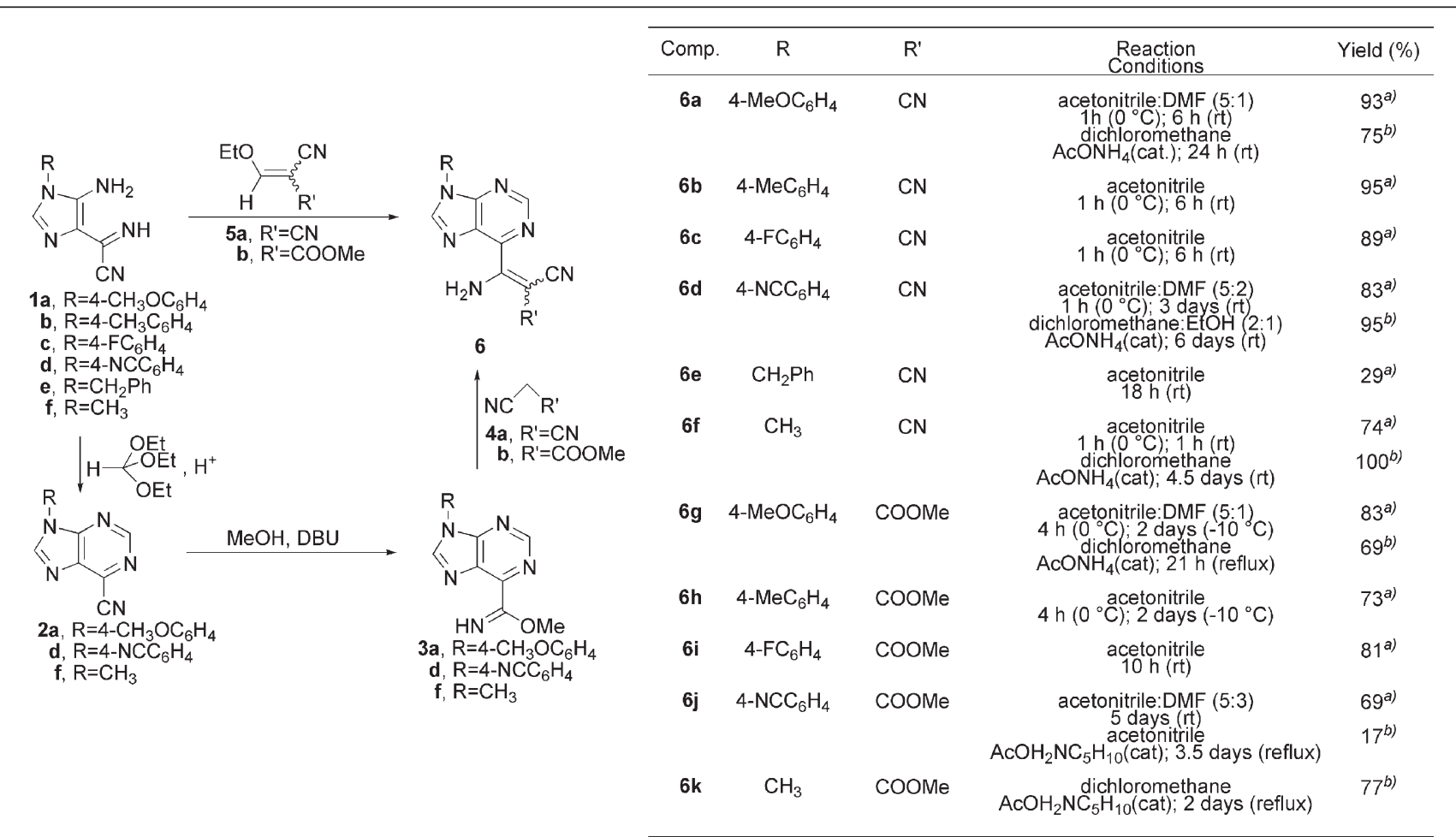

a) From the reaction of 1 and $\mathbf{5}$. ${ }^{b)}$ From the reaction of $\mathbf{3}$ and $\mathbf{4}$.

Scheme 1

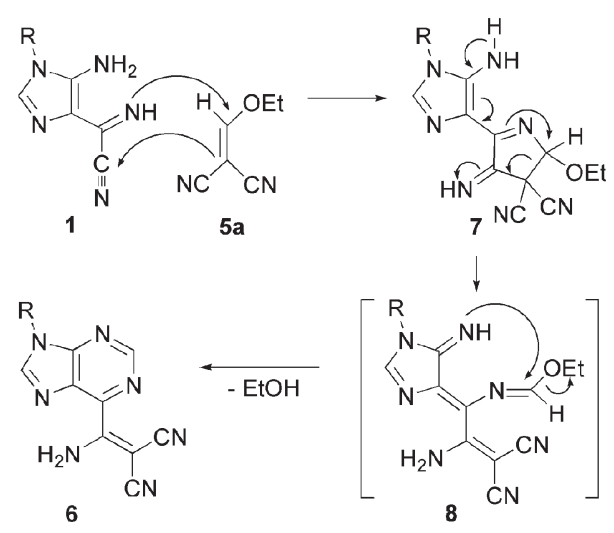

Scheme 2

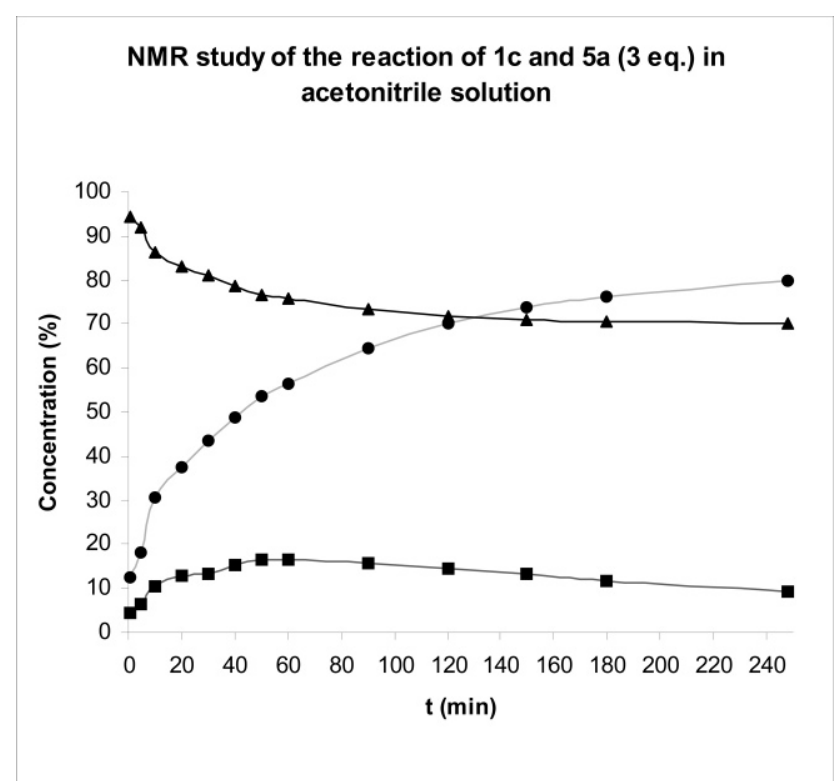

Fig. 1 The diagram represents the consumption of 5a $(\mathbf{A})$ (Me signal of the OEt group at $\delta 1.42 \mathrm{ppm}$ ), the formation of the intermediate $7 \mathbf{c}(\mathbf{\square})(\mathrm{Me}$ signal of the OEt group at $\delta 1.24 \mathrm{ppm}$ ) and its evolution to the purine $\mathbf{6 c}$ (O) (Me signal of the OEt group of EtOH at $\delta 1.17 \mathrm{ppm}$ ).<smiles>COc1ccc(/N=C/N/C(C#N)=C(/N)C#N)cc1</smiles>

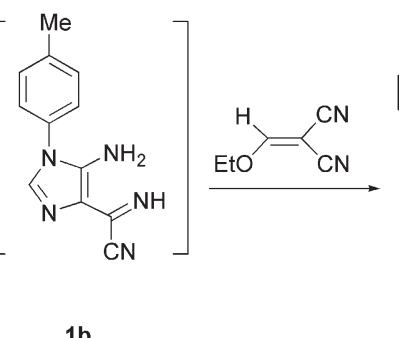

Scheme 3
$6 b$

proton, or to a broad singlet between $\delta 9.20-9.30 \mathrm{ppm}$ integrating for two protons $(\mathbf{6 c})$. The two signals in the $\delta 9.0-9.4 \mathrm{ppm}$ region for the two $\mathrm{C}-\mathrm{H}$ protons on $\mathrm{C}-2$ and $\mathrm{C}-8$ support the presence of the purine ring. For purines $\mathbf{6 i - k}$, the IR spectrum shows the cyano group as an intense band around $2210 \mathrm{~cm}^{-1}$ and the stretching vibration of the carbonyl group is also an intense band in the $1675-1715 \mathrm{~cm}^{-1}$ region. The presence of these two functional groups is confirmed in the ${ }^{13} \mathrm{C}$ NMR spectrum, as two peaks are always present around $\delta 118 \mathrm{ppm}(\mathrm{CN})$ and $\delta 164 \mathrm{ppm}(\mathrm{CO})$. The chemical shifts for both carbon atoms of the alkene substituent in the 6-position of the purine ring are also typical of these compounds and reflect the effect of the substituent. The carbon atom directly bonded to the amino group gives a signal around $\delta 167 \mathrm{ppm}$, while the adjacent carbon (bonded to the cyano and ester groups) leads to a small band around $\delta 71 \mathrm{ppm}$. In the ${ }^{1} \mathrm{H}$ NMR spectrum, the amino group leads to two singlets around $\delta 9.20 \mathrm{ppm}$ and $\delta 9.40 \mathrm{ppm}$, each one integrating for one proton, and the two signals in the $\delta 9.1-9.4 \mathrm{ppm}$ region for the two $\mathrm{C}-\mathrm{H}$ protons on $\mathrm{C}-2$ and $\mathrm{C}-8$ are indicative of the purine ring.

Further support for the structure of purines $\mathbf{6}$ was obtained when the same compounds were prepared by the reaction of 6-(methoxyformimidoyl)purines $\mathbf{3}$ and malononitrile or methylcyanoacetate (Scheme 1). The synthesis of 6-(methoxyformimidoyl)purines 3 has been recently reported and occurs in excellent yield from the reaction of 6-cyanopurines 2 with methanol in the presence of DBU. ${ }^{9}$ The 6-cyanopurines used in this work were prepared in a simple and efficient way from the reaction of imidazoles 1 with triethylorthoformate in the presence of sulfuric acid or with dimethylformamide diethylacetal. ${ }^{10}$

The chemistry of the imidate function has been thoroughly reviewed ${ }^{11}$ and indicates that this functional group is susceptible to 
nucleophilic substitution, that usually occurs with elimination of the ether function. In the present work, a detailed study was carried out on the reaction of purines $\mathbf{3 a}, \mathbf{3 d}$ and $\mathbf{3 f}$ with malononitrile and methylcyanoacetate, in order to generate the corresponding 6 -enaminopurines $\mathbf{6}$. This reaction is very slow or does not occur in the absence of mild acid catalysis, even when an excess of the carbon acid is used (1.1-1.4 equivalents) and under reflux conditions in acetonitrile or dichloromethane. When ammonium acetate or piperidinium acetate were used as catalysts and the reaction was carried out under reflux in acetonitrile or dichloromethane, the 6-enaminopurine was formed and precipitated from the reaction mixture on cooling. The reaction of 9-(4-cyanophenyl)-6(methoxyformimidoyl)purine 3d with methylcyanoacetate is slow even in the presence of pyridinium acetate. In order to overcome this problem, four equivalents of methylcyanoacetate were used and the reflux in acetonitrile was maintained for up to 8 days. The experimental conditions favored ring opening of the 6-enaminopurine ring, leading to the formation of pyrimido-pyrimidine 10a in variable quantities (Scheme 4). A small amount of purine $\mathbf{6 j}(17 \%)$ could be isolated when 6-(methoxyformimidoyl)purine 3d and methylcyanoacetate (4 equivalents) were refluxed in acetonitrile for 3.5 days, in the presence of a catalytic amount of piperidinium acetate. In this reaction, compound $\mathbf{1 0 a}$ was isolated as the major product $(53 \%)$. When the acid catalysis was replaced by base catalysis (DBU), the only product isolated after 2 days under reflux in dry acetonitrile was the pyrimido-pyrimidine 10a (40\%). The use of an excess of base (DMAP, 6 equivalents) also caused ring opening of the 6-(methoxyformimidoyl)purine, and the solid isolated was a mixture of pyrimido-pyrimidines $\mathbf{1 0 a}$ and $\mathbf{1 1}$ in a $1: 3$ molar ratio, as indicated by ${ }^{1} \mathrm{H}$ NMR spectroscopy (Scheme 5). Ring opening of the 6-enaminopurine was confirmed when compound $\mathbf{6 g}$ was reacted with methylcyanoacetate ( 8 equivalents) in the presence of DMAP (1.3 equivalents). The only product isolated from the reaction mixture was the pyrimido-pyrimidine $\mathbf{1 0 b}(70 \%)$. The observation that direct ring opening of purine $\mathbf{3 d}$ is favored by the addition of an excess of base, indicates that when a high concentration of the methyl cyanoacetate anion is present, competitive nucleophilic attack on C-8 of the purine ring occurs to give the pyrimido-pyrimidine $\mathbf{1 1}$ through an ANRORC type mechanism, as is represented in Scheme 5. This pathway must be facilitated by the electron-withdrawing effect of the aryl substituent on N-9. Under mild acid catalysis the concentration of the carbon acid in solution is high and protonation of the imidate function also occurs, activating it for nucleophilic attack, resulting in 6-enaminopurine formation (Scheme 5).

\section{Conclusion}

The reaction of 5-amino-4-(cyanoformimidoyl)imidazoles $\mathbf{1}$ with ethoxymethylenemalononitrile $\mathbf{5 a}$ or ethoxymethylenecyanoacetate $\mathbf{5 b}$ occurs selectively on the cyanoformimidoyl substituent. An imidazo-pyrrolidine structure was postulated for the intermediate, which rapidly evolves to the 6-enaminopurine 6 , isolated in very good yield. The electronic effect of the substituent on $\mathrm{N}-1$ of the imidazole ring does not seem to affect the efficiency of this reaction.

The same 6-enaminopurines were isolated from the reaction of 6-(methoxyformimidoyl) purines $\mathbf{3}$ with malononitrile $4 \mathbf{a}$ or methylcyanoacetate $\mathbf{4 b}$, in the presence of mild acid catalysis. Although this reaction sequence requires three steps, starting from imidazole 1 , the overall yield is only slightly lower when compared to the other synthetic method, as the 6-cyanopurines 2 and the 6-(methoxyform imidoyl)purines $\mathbf{3}$ can be prepared in almost quantitative yields. ${ }^{9}$ Major problems were faced when purine $\mathbf{3 d}\left(\mathrm{R}=4-\mathrm{NCC}_{6} \mathrm{H}_{4}\right)$ was reacted with methylcyanoacetate $\mathbf{4 b}$. The reaction does not occur or is rather slow in the presence of acid catalysis and the addition of base causes ring opening of the imidazole ring in purine $\mathbf{3 d}$ and/or $\mathbf{6 j}$ leading to pyrimido-pyrimidines $\mathbf{1 1}$ and $\mathbf{1 0}$ respectively.

\section{Experimental section}

IR Spectra were recorded on a Perkin-Elmer 1600 series FTIR spectrometer, ${ }^{1} \mathrm{H}$ and ${ }^{13} \mathrm{C}$ NMR spectra on a Varian Unity Plus spectro-
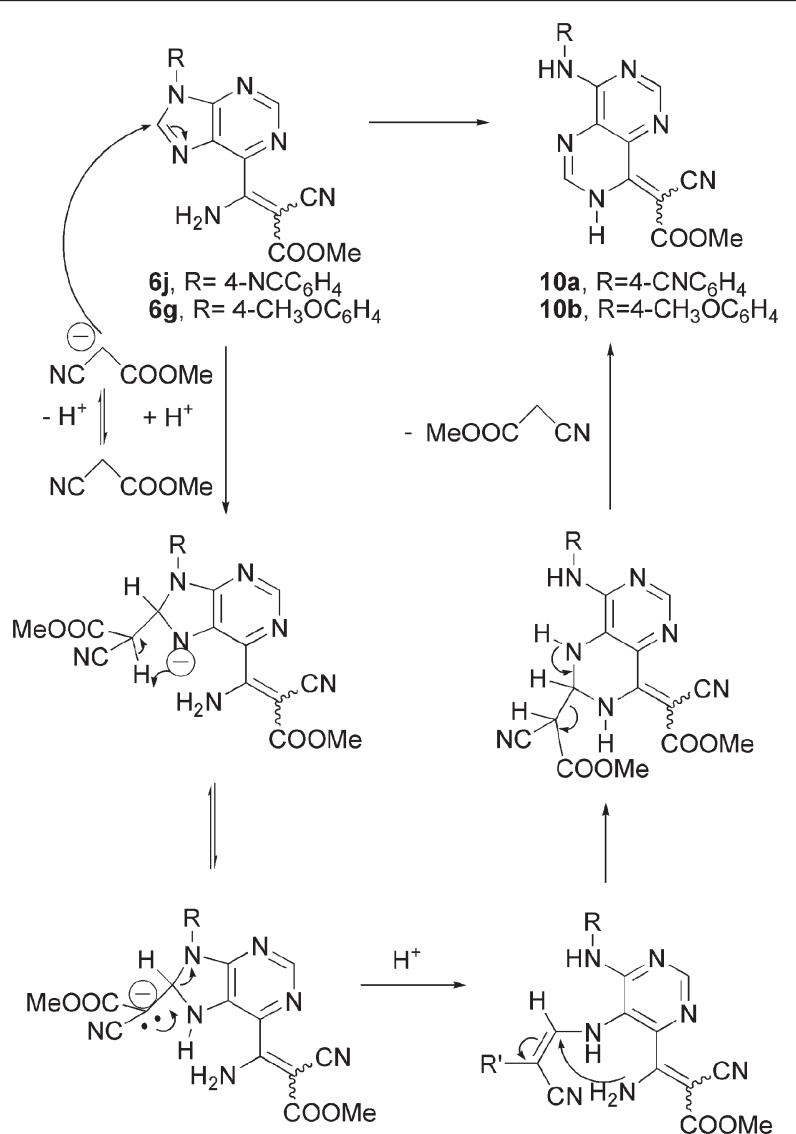

Scheme 4

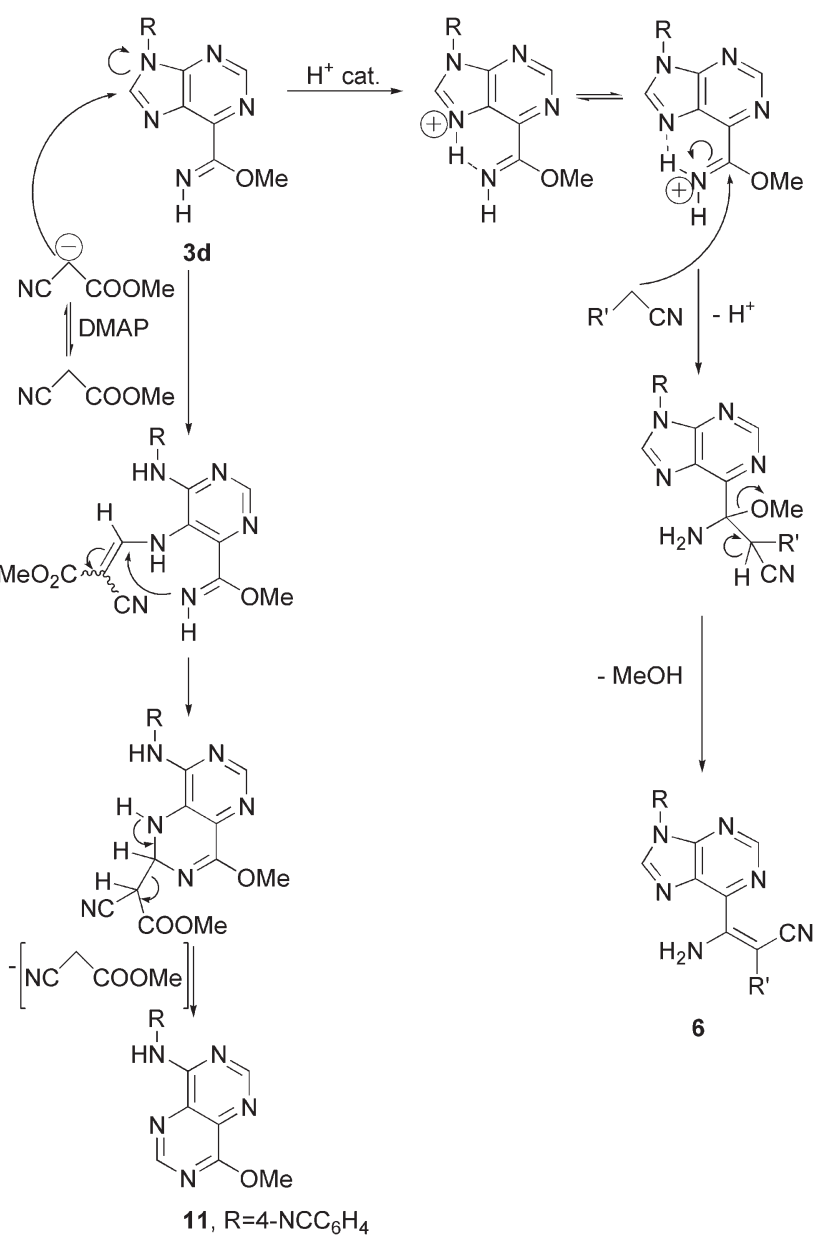

Scheme 5 
meter. Mass spectra were recorded on a GC-MS Automass 120 or on a Kratos Concept instrument.

The 6-cyanopurines $\mathbf{2 a}, \mathbf{2} \mathbf{d}$ and $\mathbf{2} \mathbf{f}$ were prepared according to the experimental procedure described in the literature. ${ }^{10}$ These compounds were used as precursors of the corresponding 6(methoxyformimidoyl)purines $\mathbf{3 a}, \mathbf{3 d}$ and $\mathbf{3 f}$ using previously described experimental procedures. ${ }^{9}$

General procedure for the reaction of 5-amino-1-aryl-4-(cyanoformimidoyl)imidazoles 1 with ethoxymethylenemalononitrile

A suspension of 5-amino-1-aryl-4-(cyanoformimidoyl)imidazole 1a-d $(0.41-0.44 \mathrm{mmol})$ in acetonitrile $(5 \mathrm{~mL})$ and DMF $(1 \mathrm{~mL})$ for $1 \mathbf{a}$, acetonitrile $(5 \mathrm{~mL})$ for $\mathbf{1 b}$ and $\mathbf{1 c}$ or acetonitrile $(5 \mathrm{~mL})$ and DMF $(2 \mathrm{~mL})$ for $\mathbf{1 d}$, was combined with ethoxymethylenemalononitrile $(0.66 \mathrm{mmol})$ at $0{ }^{\circ} \mathrm{C}$. The mixture was stirred in the ice bath for $1 \mathrm{~h}$ and then at room temperature for $6 \mathrm{~h}$ (for 1a-c) or $72 \mathrm{~h}$ (for 1d). The suspension was filtered and washed with diethyl ether. The product was identified as 6-(1-amino-2,2-dicyanovinyl)-9-arylpurine 6a-d.

General procedure for the reaction of 1-alkyl-5-amino-4(cyanoformimidoyl)imidazoles 1 with ethoxymethylenemalononitrile

A solution of 1-alkyl-5-amino-4-(cyanoformimidoyl)imidazole 1e, $\mathbf{f}(0.45-0.54 \mathrm{mmol})$ in acetonitrile $(5 \mathrm{~mL})$ was combined with ethoxymethylenemalononitrile $(0.66 \mathrm{mmol})$ at $0{ }^{\circ} \mathrm{C}$ (for $\mathbf{1 f}$ ) or room temperature (for 1e). The solution was stirred in the ice bath for $1 \mathrm{~h}$ and then at room temperature for $1 \mathrm{~h}$ (for $\mathbf{1 f}$ ) or $18 \mathrm{~h}$ (for $\mathbf{1 e}$ ). Compound $\mathbf{6 f}$ precipitates from the reaction mixture and was filtered and washed with diethyl ether. Compound $\mathbf{6 e}$ remains in solution, which is concentrated in the rotary evaporator. This product was precipitated by addition of dichloromethane and was filtered and washed with dichloromethane. The product was identified as 6-(1amino-2,2-dicyanovinyl)-9-alkylpurine $6 \mathbf{e}, \mathbf{f}$.

General procedure for the reaction of 5-amino-1-aryl-4-(cyanoformimidoyl)imidazoles 1 with ethoxymethylenecyanoacetate

A suspension of 5-amino-1-aryl-4-(cyanoformimidoyl)imidazole 1a-d (0.40-0.44 mmol) in acetonitrile $(5 \mathrm{~mL})$ and DMF $(1 \mathrm{~mL})$ for $\mathbf{1 a}$, acetonitrile $(5 \mathrm{~mL})$ for $\mathbf{1 b}$ and $\mathbf{1 c}$ or acetonitrile $(5 \mathrm{~mL})$ and DMF $(3 \mathrm{~mL})$ for $\mathbf{1 d}$, was combined with ethoxymethylenecyanoacetate $(0.60-0.90 \mathrm{mmol})$ at $0{ }^{\circ} \mathrm{C}$ (for $\mathbf{1 a}, \mathbf{1 b}$ ) or room temperature (for $\mathbf{1 c}$, 1d). The mixture was stirred in the ice bath for $4 \mathrm{~h}$ and than for 2 days at $-10{ }^{\circ} \mathrm{C}$ (for $\mathbf{1 a}$ and $\mathbf{1 b}$ ), for $10 \mathrm{~h}$ at room temperature (for $\mathbf{1 c}$ ) or for 5 days at room temperature (for $1 \mathrm{~d}$ ). Compounds $6 \mathrm{~g}, \mathbf{6 h}$ and $6 \mathbf{i}$ precipitate out of solution and were filtered and washed with ethanol. Compound $\mathbf{6 j}$ remains in solution, which is concentrated in the rotary evaporator. The product was precipitated by addition of diethyl ether and was filtered and washed with ether. The solid was identified as 6-(1-amino-2-cyano-2-methoxycarbonylvinyl)-9-aryl purine $\mathbf{6 g}-\mathbf{j}$.

Synthesis of 9-(4-toluyl)-6-(1-amino-2,2-dicyanovinyl)purine 6 from $N$-(4-toluyl)- $N$ '-(2-amino-1,2-dicyanovinyl)formamidine 9 and ethoxymethylenecyanoacetate

A suspension of $N$-(4-toluyl)- $N$ '-(2-amino-1,2-dicyanovinyl)formamidine $(0.10 \mathrm{~g}, 0.44 \mathrm{mmol})$ in ethanol $(5 \mathrm{~mL})$ was combined with one drop of DBU and the mixture was stirred at room temperature for $10 \mathrm{~min}$ and then placed in an ice bath. Ethoxymethylenecyanoacetate $(0.09 \mathrm{~g}, 0.74 \mathrm{mmol})$ was added and the mixture was stirred at $0{ }^{\circ} \mathrm{C}$ for $1 \mathrm{~h}$ followed by $6 \mathrm{~h}$ at room temperature. The product precipitates out of solution and was filtered and washed with diethyl ether. The solid was identified as the title compound (0.12 g, $0.40 \mathrm{mmol}, 91 \%)$.

\section{9-(4-Methoxyphenyl)-6-(1-amino-2,2-dicyanovinyl)purine (6a)}

Mp 309-310 ${ }^{\circ} \mathrm{C}$; (Found: C, 59.97; H, 3.75; N, 30.16. Calc. for $\mathrm{C}_{16} \mathrm{H}_{11} \mathrm{~N}_{7} \mathrm{O} .0 .25 \mathrm{H}_{2} \mathrm{O}:$ C, 59.72; H, 3.58; N, 30.48\%); IR (Nujol mull): $v_{\max } / \mathrm{cm}^{-1} 2216 \mathrm{~s}(\mathrm{CN}), 2206 \mathrm{~m}(\mathrm{CN}), 1665 \mathrm{~s}, 1579 \mathrm{~m}, 1544 \mathrm{~s}$; $\delta_{\mathrm{H}}\left(300 \mathrm{MHz} ;\left(\mathrm{CD}_{3}\right)_{2} \mathrm{SO}\right) 9.40(1 \mathrm{H}$, br s, NH), $9.17(>1 \mathrm{H}, \mathrm{s}, 8-\mathrm{H}$ and $\mathrm{NH}), 9.15(1 \mathrm{H}, \mathrm{s}, 2-\mathrm{H}), 7.81(2 \mathrm{H}, \mathrm{d}, J 6.9 \mathrm{~Hz}, \mathrm{Ar}-\mathrm{H}), 7.20$ $(2 \mathrm{H}, \mathrm{d}, J 6.9 \mathrm{~Hz}, \mathrm{Ar}-\mathrm{H}), 3.84(3 \mathrm{H}, \mathrm{s}, \mathrm{OMe}) ; \delta_{\mathrm{C}}\left(75 \mathrm{MHz} ;\left(\mathrm{CD}_{3}\right)_{2} \mathrm{SO}\right)$ $165.4,159.2,152.2,148.9,148.0,131.0,126.6,125.4,115.7,114.9$, $114.8,55.6,50.4$.

\section{9-(4-Toluyl)-6-(1-amino-2,2-dicyanovinyl)purine (6b)}

Mp 298-299 ${ }^{\circ} \mathrm{C}$; (Found: C, 63.03; H, 3.95; N, 31.97. Calc. for $\mathrm{C}_{16} \mathrm{H}_{11} \mathrm{~N}_{7} .0 .20 \mathrm{H}_{2} \mathrm{O}$ : C, 63.03; H, 3.74; N, 32.17\%); IR (Nujol mull): $v_{\max } / \mathrm{cm}^{-1} 2207 \mathrm{~s}(\mathrm{CN}), 1662 \mathrm{~s}, 1545 \mathrm{~s} ; \delta_{\mathrm{H}}\left(300 \mathrm{MHz} ;\left(\mathrm{CD}_{3}\right)_{2} \mathrm{SO}\right) 9.41$ (1 H, s, NH), $9.21(1 \mathrm{H}, \mathrm{s}, 2-\mathrm{H}), 9.16(1 \mathrm{H}, \mathrm{s}, 8-\mathrm{H}), 7.80(2 \mathrm{H}, \mathrm{d}$, $J 8.3 \mathrm{~Hz}, \mathrm{Ar}-\mathrm{H}), 7.45(2 \mathrm{H}, \mathrm{d}, J 8.3 \mathrm{~Hz}, \mathrm{Ar}-\mathrm{H}), 2.41(3 \mathrm{H}, \mathrm{s}, \mathrm{Me})$; $\delta_{\mathrm{C}} \mathrm{NMR}\left(75 \mathrm{MHz} ;\left(\mathrm{CD}_{3}\right)_{2} \mathrm{SO}\right) 165.4,152.3,152.1,148.0,147.7$, $138.3,131.4,131.2,130.2,123.6,115.7,114.9,50.5,20.7$.

\section{9-(4-Fluorophenyl)-6-(1-amino-2,2-dicyanovinyl)purine (6c)}

Mp 314-315 ${ }^{\circ} \mathrm{C}$; (Found: C, 59.05; H, 2.88. Calc. for $\mathrm{C}_{15} \mathrm{H}_{8} \mathrm{~N}_{7} \mathrm{~F}$ : C, 59.02; H, 2.62\%); IR (Nujol mull): $v_{\max } / \mathrm{cm}^{-1} 2217 \mathrm{~s}(\mathrm{CN}), 2200 \mathrm{~s}$ $(\mathrm{CN}), 1665 \mathrm{~s}, 1580 \mathrm{~m}, 1550 \mathrm{~s}, 1517 \mathrm{~s} ; \delta_{\mathrm{H}}\left(300 \mathrm{MHz} ;\left(\mathrm{CD}_{3}\right)_{2} \mathrm{SO}\right) 9.27$ (2 H, br s, $\left.\mathrm{NH}_{2}\right), 9.19(1 \mathrm{H}, \mathrm{s}, 2-\mathrm{H}), 9.16(1 \mathrm{H}, \mathrm{s}, 8-\mathrm{H}), 7.96$ (2 H, dd, $J 9.0 \mathrm{~Hz}, J 4.5 \mathrm{~Hz}, \mathrm{Ar}-\mathrm{H}), 7.51(2 \mathrm{H}, \mathrm{t}, J 9.0 \mathrm{~Hz}, \mathrm{Ar}-\mathrm{H}) ; \delta_{\mathrm{C}} \mathrm{NMR}$ $\left(75 \mathrm{MHz} ;\left(\mathrm{CD}_{3}\right)_{2} \mathrm{SO}\right) 165.4,163.2(\mathrm{~d}, J 244 \mathrm{~Hz}), 152.4,152.3$, 148.1, 147.8, 131.2, $130.2(\mathrm{~d}, J 3 \mathrm{~Hz}), 126.3(\mathrm{~d}, J 9 \mathrm{~Hz}), 116.8(J$ $23 \mathrm{~Hz}), 115.8,115.0,50.6$.

\section{9-(4-Cyanophenyl)-6-(1-amino-2,2-dicyanovinyl)purine (6d)}

Mp $270{ }^{\circ} \mathrm{C}$ (dec.); IR (Nujol mull): $v_{\max } / \mathrm{cm}^{-1} 2234 \mathrm{w}$ (CN), 2219m $(\mathrm{CN}), 2205 \mathrm{~m}(\mathrm{CN}), 1661 \mathrm{~m}, 1534 \mathrm{~s}, 1519 \mathrm{~s} ; \delta_{\mathrm{H}}\left(300 \mathrm{MHz} ;\left(\mathrm{CD}_{3}\right)_{2} \mathrm{SO}\right)$ $9.42(1 \mathrm{H}, \mathrm{s}, \mathrm{NH}), 9.38(1 \mathrm{H}, \mathrm{s}, 2-\mathrm{H}), 9.22(1 \mathrm{H}, \mathrm{s}, 8-\mathrm{H}), 9.18(1 \mathrm{H}$, s, NH), $8.28(2 \mathrm{H}, \mathrm{d}, J 8.4 \mathrm{~Hz}, \mathrm{Ar}-\mathrm{H}), 8.17(2 \mathrm{H}, \mathrm{d}, J 8.4 \mathrm{~Hz}, \mathrm{Ar}-\mathrm{H})$; $\delta_{\mathrm{C}}\left(75 \mathrm{MHz} ;\left(\mathrm{CD}_{3}\right)_{2} \mathrm{SO}\right) 165.2$, 152.6, 152.0, 148.4, 147.3, 137.7, 134.0, 131.6, 123.8, 118.2, 115.7, 114.8, 110.8, 50.6. HRMS (FAB) $m / z(F A B) 313.096447\left((\mathrm{M}+\mathrm{H})^{+} . \mathrm{C}_{16} \mathrm{H}_{8} \mathrm{~N}_{8}\right.$ requires 313.095017).

\section{9-Benzyl-6-(1-amino-2,2-dicyanovinyl)purine (6e)}

Mp $187-189^{\circ} \mathrm{C}\left(\mathrm{dec}\right.$.); $\delta_{\mathrm{H}}\left(300 \mathrm{MHz} ;\left(\mathrm{CD}_{3}\right)_{2} \mathrm{SO}\right) 9.35(1 \mathrm{H}, \mathrm{s}, \mathrm{NH})$, $9.11(1 \mathrm{H}, \mathrm{s}, 2-\mathrm{H}), 9.10(1 \mathrm{H}, \mathrm{s}, \mathrm{NH}), 8.99(1 \mathrm{H}, \mathrm{s}, 8-\mathrm{H}), 7.35(5 \mathrm{H}$, $\mathrm{m}, \mathrm{Ph}), 5.57\left(2 \mathrm{H}, \mathrm{s}, \mathrm{CH}_{2} \mathrm{Ph}\right) ; \delta_{\mathrm{C}}\left(75 \mathrm{MHz} ;\left(\mathrm{CD}_{3}\right)_{2} \mathrm{SO}\right) 165.5,152.4$, 151.8, 148.8, 147.6, 136.1, 130.7, 128.8, 128.2, 127.9, 115.7, 114.9, 46.9.

\section{9-Methyl-6-(1-amino-2,2-dicyanovinyl)purine (6f)}

Mp $268^{\circ} \mathrm{C}$ (dec.); IR (Nujol mull): $v_{\max } / \mathrm{cm}^{-1} 2220 \mathrm{~m}(\mathrm{CN}), 2202 \mathrm{~m}$ $(\mathrm{CN}), 1662 \mathrm{~m}, 1586 \mathrm{~m}, 1553 \mathrm{~s}, 1504 \mathrm{~m} ; \delta_{\mathrm{H}}\left(300 \mathrm{MHz} ;\left(\mathrm{CD}_{3}\right)_{2} \mathrm{SO}\right)$ $9.22\left(2 \mathrm{H}\right.$, br s, $\left.\mathrm{NH}_{2}\right), 9.10(1 \mathrm{H}, \mathrm{s}, 2-\mathrm{H}), 8.77(1 \mathrm{H}, \mathrm{s}, 8-\mathrm{H}), 3.90$ $(3 \mathrm{H}, \mathrm{s}, \mathrm{Me}) ; \delta_{\mathrm{C}}\left(75 \mathrm{MHz} ;\left(\mathrm{CD}_{3}\right)_{2} \mathrm{SO}\right) 165.6,152.9,151.5,149.5$, $147.1,130.5,115.8,115.0,50.3,30.0$. HRMS (FAB) $\mathrm{m} / \mathrm{z}$ (FAB) $226.0843444\left((\mathrm{M}+\mathrm{H})^{+} . \mathrm{C}_{10} \mathrm{H}_{7} \mathrm{~N}_{7}\right.$ requires 226.084118).

\section{9-(4-Methoxyphenyl)-6-(1-amino-2-cyano-2-methoxy-} carbonylvinyl)purine (6g)

Mp 222-224 ${ }^{\circ} \mathrm{C}$; (Found: C, 58.04; H, 4.22; N, 23.64. Calc. for $\mathrm{C}_{17} \mathrm{H}_{14} \mathrm{~N}_{6} \mathrm{O}_{3}$ : C, 52.28; H, 4.03; N, 23.99\%); IR (Nujol mull): $v_{\max } / \mathrm{cm}^{-1} 2195 \mathrm{~m}(\mathrm{CN}), 1677 \mathrm{~m}(\mathrm{CO}), 1611 \mathrm{~m}, 1576 \mathrm{~m}, 1520 \mathrm{~s} ; \delta_{\mathrm{H}}$ (300 MHz; $\left.\left(\mathrm{CD}_{3}\right)_{2} \mathrm{SO}\right) 9.36(1 \mathrm{H}, \mathrm{s}, \mathrm{NH}), 9.19(1 \mathrm{H}, \mathrm{s}, \mathrm{NH}), 9.13$ $(1 \mathrm{H}, \mathrm{s}, 8-\mathrm{H}), 9.12(1 \mathrm{H}, \mathrm{s}, 2-\mathrm{H}), 7.81(2 \mathrm{H}, \mathrm{d}, J 9.0 \mathrm{~Hz}, \mathrm{Ar}-\mathrm{H})$, 7.19 (2 H, d, J $9.0 \mathrm{~Hz}, \mathrm{Ar}-\mathrm{H}), 3.85$, (3 H, s, OMe), 3.76 (3 H, s, COOMe); $\delta_{\mathrm{C}}\left(75 \mathrm{MHz} ;\left(\mathrm{CD}_{3}\right)_{2} \mathrm{SO}\right) 167.0,163.9,159.1,152.3$, 151.9, 150.1, 147.4, 131.1, 126.7, 125.3, 114.9, 71.2, 55.6, 51.6.

\section{9-(4-Toluyl)-6-(1-amino-2-cyano-2-methoxycarbonyl- vinyl)purine (6h)}

Mp 242-243 ${ }^{\circ} \mathrm{C}$; (Found: C, 61.28; H, 4.42; N, 25.03. Calc. for $\mathrm{C}_{17} \mathrm{H}_{14} \mathrm{~N}_{6} \mathrm{O}_{2}$ : C, 61.07; H, 4.22; N, 25.14\%); $\delta_{\mathrm{H}}(300 \mathrm{MHz}$; $\left.\left(\mathrm{CD}_{3}\right)_{2} \mathrm{SO}\right) 9.37(1 \mathrm{H}, \mathrm{s}, \mathrm{NH}), 9.20(1 \mathrm{H}, \mathrm{s}, \mathrm{NH}), 9.17(1 \mathrm{H}, \mathrm{s}$, 8-H), 9.15 (1 H, s, 2-H), $7.82(2 \mathrm{H}, \mathrm{d}, J 8.4 \mathrm{~Hz}, \mathrm{Ar}-\mathrm{H}), 7.46(2 \mathrm{H}$, d, $J 8.4 \mathrm{~Hz}, \mathrm{Ar}-\mathrm{H}), 3.76,(3 \mathrm{H}, \mathrm{s}, \mathrm{COOMe}), 2.41(3 \mathrm{H}, \mathrm{s}, \mathrm{Me}) ; \delta_{\mathrm{C}}$ 
(75 MHz; $\left.\left(\mathrm{CD}_{3}\right)_{2} \mathrm{SO}\right) 166.9,163.8,152.3,151.8,150.2,147.2$, 138.1, 131.4, 131.2, 130.1, 123.4, 117.6, 71.2, 51.5, 20.7.

\section{9-(4-Fluorophenyl)-6-(1-amino-2-cyano-2-methoxycarbonyl- vinyl)purine (6i)}

Mp 250-254 ${ }^{\circ} \mathrm{C}$ (dec); (Found: C, 56.73; H, 3.62. Calc. for $\mathrm{C}_{16} \mathrm{H}_{11} \mathrm{~N}_{6} \mathrm{O}_{2} \mathrm{~F}$ : C, 56.81; H, 3.28\%); IR (Nujol mull): $v_{\max } / \mathrm{cm}^{-1} 2208 \mathrm{~s}$ $(\mathrm{CN}), 1676 \mathrm{~m}(\mathrm{CO}), 1626 \mathrm{~s}, 1582 \mathrm{~m}, 1573 \mathrm{~s}, 1524 \mathrm{~s} ; \delta_{\mathrm{H}}(300 \mathrm{MHz}$; $\left.\left(\mathrm{CD}_{3}\right)_{2} \mathrm{SO}\right) 9.38(1 \mathrm{H}, \mathrm{s}, \mathrm{NH}), 9.22(1 \mathrm{H}, \mathrm{s}, \mathrm{NH}), 9.19(1 \mathrm{H}, \mathrm{s}, 8-\mathrm{H})$, $9.16(1 \mathrm{H}, \mathrm{s}, 2-\mathrm{H}), 8.00(2 \mathrm{H}, \mathrm{dd}, J 9.0 \mathrm{~Hz}, J 4.8 \mathrm{~Hz}, \mathrm{Ar}-\mathrm{H}), 7.52(2 \mathrm{H}$, t, $J 9.0 \mathrm{~Hz}, \mathrm{Ar}-\mathrm{H}), 3.76(3 \mathrm{H}, \mathrm{s}, \mathrm{COOMe}) ; \delta_{\mathrm{C}}\left(75 \mathrm{MHz} ;\left(\mathrm{CD}_{3}\right)_{2} \mathrm{SO}\right)$ 167.0, 163.8, $161.6(\mathrm{~d}, J 245 \mathrm{~Hz}), 152.5,151.9,150.2,147.3,131.2$, 130.3, 126.1 (d, $J 9 \mathrm{~Hz}), 117.7,116.7(\mathrm{~d}, J 23 \mathrm{~Hz}), 71.2,51.6$.

\section{9-(4-Cyanophenyl)-6-(1-amino-2-cyano-2-methoxycarbonyl- vinyl)purine (6j)}

Mp $204{ }^{\circ} \mathrm{C}$ (dec.); (Found: C, 59.28; H, 3.29; N, 28.34. Calc. for $\mathrm{C}_{17} \mathrm{H}_{11} \mathrm{~N}_{7} \mathrm{O}_{2}$ : C, 59.13; H, 3.19; N, 28.41\%); IR (Nujol mull): $v_{\max } / \mathrm{cm}^{-1} 2230 \mathrm{~m}(\mathrm{CN}), 2208 \mathrm{~m}(\mathrm{CN}), 1664 \mathrm{~m}(\mathrm{CO}), 1615 \mathrm{~m}, 1579 \mathrm{~m}$; $\delta_{\mathrm{H}}\left(300 \mathrm{MHz} ;\left(\mathrm{CD}_{3}\right)_{2} \mathrm{SO}\right) 9.37(1 \mathrm{H}, \mathrm{s}, 8-\mathrm{H}), 9.35(1 \mathrm{H}, \mathrm{s}, \mathrm{NH}), 9.22$ $(2 \mathrm{H}, \mathrm{s}, 2-\mathrm{H}$ and $\mathrm{NH}), 8.30(2 \mathrm{H}, \mathrm{d}, J 8.7 \mathrm{~Hz}, \mathrm{Ar}-\mathrm{H}), 8.17(2 \mathrm{H}, \mathrm{d}$, $J 8.7 \mathrm{~Hz}, \mathrm{Ar}-\mathrm{H}), 3.76(3 \mathrm{H}, \mathrm{s}, \mathrm{COOMe}) ; \delta_{\mathrm{C}}\left(75 \mathrm{MHz} ;\left(\mathrm{CD}_{3}\right)_{2} \mathrm{SO}\right)$ $166.9,163.6,152.6,151.6,150.5,146.9,137.8,134.1,131.6,123.6$, $118.2,117.6,110.6,71.5,51.6$.

\section{9-Methyl-6-(1-amino-2-cyano-2-methoxycarbonylvinyl)purine (6k)}

Mp 206-207 ${ }^{\circ} \mathrm{C}$; (Found: C, 50.97; H, 3.91; N, 32.32. Calc. for $\mathrm{C}_{11} \mathrm{H}_{10} \mathrm{~N}_{6} \mathrm{O}:$ C, 51.16; H, 3.88; N, 32.56\%); IR (Nujol mull): $v_{\max } / \mathrm{cm}^{-1} 2208 \mathrm{~m}(\mathrm{CN}), 1683 \mathrm{~m}(\mathrm{CO}), 1630 \mathrm{~m}, 1593 \mathrm{~m}, 1580 \mathrm{~m}$, $1530 \mathrm{~s} ; \delta_{\mathrm{H}}\left(300 \mathrm{MHz} ;\left(\mathrm{CD}_{3}\right)_{2} \mathrm{SO}\right) 9.33(1 \mathrm{H}, \mathrm{s}, \mathrm{NH}), 9.17(1 \mathrm{H}, \mathrm{br} \mathrm{s}$, $\mathrm{NH}), 9.08(1 \mathrm{H}, \mathrm{s}, 2-\mathrm{H}), 8.72(1 \mathrm{H}, \mathrm{s}, 8-\mathrm{H}), 3.90(3 \mathrm{H}, \mathrm{s}, \mathrm{Me}), 3.73$ $(3 \mathrm{H}, \mathrm{s}, \mathrm{COOMe}) ; \delta_{\mathrm{C}}\left(75 \mathrm{MHz} ;\left(\mathrm{CD}_{3}\right)_{2} \mathrm{SO}\right) 167.0,164.2,152.7$, $151.6,149.3,149.0,130.5,117.7,71.1,51.5,29.9$.

\section{General procedure for the reaction of 9-aryl-6-(methoxy- formimidoyl)purine 3 with malononitrile}

A suspension of 9-aryl-6-(methoxyformimidoyl)purine 3 $(0.55 \mathrm{mmol})$ in dichloromethane $(5 \mathrm{~mL})$ for $\mathbf{3 a}$ or dichloromethane $(4 \mathrm{~mL})$ and ethanol $(2 \mathrm{~mL})$ for $\mathbf{3 d}$, was combined with malononitrile $(0.84 \mathrm{mmol})$ and a catalytic amount of ammonium acetate, at room temperature. The mixture was stirred for 1 day (for $\mathbf{3 a}$ ) or 6 days (for 3d). The suspension was filtered and washed with diethyl ether. A second crop of the same product could be obtained from the mother liquor after concentration in the rotary evaporator and addition of diethyl ether. The product was identified as the corresponding 6-(1-amino-2,2-dicyanovinyl)-9-arylpurines 6a and 6d.

\section{Reaction of 9-methyl-6-(methoxyformimidoyl)purine 3 f with malononitrile}

A solution of 9-methyl-6-(methoxyformimidoyl)purine $\mathbf{3 f}(0.15 \mathrm{~g}$, $0.80 \mathrm{mmol})$ in dichloromethane $(5 \mathrm{~mL})$, was combined with malononitrile $(0.07 \mathrm{~g}, 1.12 \mathrm{mmol})$ and a catalytic amount of ammonium acetate, at room temperature and with efficient stirring. A cream solid started to be formed after $10 \mathrm{~min}$, and the mixture was stirred for 4.5 days, when the tlc showed the absence of the starting material. The suspension was filtered and washed with diethyl ether. The product was identified as the 6-(1-amino-2,2-dicyanovinyl)-9methyl purine $\mathbf{6 f}$.

\section{Reaction of 9-(4-methoxphenyl)-6-(methoxyformimidoyl)- purine 3a with methylcyanoacetate}

A suspension of 9-(4-methoxyphenyl)-6-(methoxyformimidoyl)purine 3a $(0.15 \mathrm{~g}, 0.55 \mathrm{mmol})$ in dichloromethane $(5 \mathrm{~mL})$, was combined with methylcyanoacetate $(0.22 \mathrm{~g}, 2.20 \mathrm{mmol})$ and a catalytic amount of ammonium acetate, at room temperature. The suspension was refluxed for $21 \mathrm{~h}$, when the tlc showed the absence of the starting material. The cream solid was filtered and washed with diethyl ether. The mother liquor was concentrated in the rotary evaporator leading to a second crop of the same product. The compound was identified as the 6-(1-amino-2,2-dicyanovinyl)-9(4-methoxyphenyl) purine $6 \mathrm{~g}(0.13 \mathrm{~g}, 0.38 \mathrm{mmol}, 69 \%)$.

\section{Reaction of 9-(4-cyanophenyl)-6-(methoxyformimidoyl)purine} 3d with methylcyanoacetate

Method A. A suspension of 9-(4-cyanophenyl)-6-(methoxyformimidoyl)purine $\mathbf{3 d}(0.15 \mathrm{~g}, 0.55 \mathrm{mmol})$ in acetonitrile $(20 \mathrm{~mL})$, was combined with methylcyanoacetate $(0.22 \mathrm{~g}, 2.20 \mathrm{mmol})$ and a catalytic amount of piperidinium acetate, at room temperature. The suspension was refluxed for 3.5 days, when the yellow suspension was filtered while still hot, and washed with acetonitrile and diethyl ether. This product was identified as the pyrimido-pyrimidine 10a (0.10 g, $0.29 \mathrm{mmol}, 53 \%) ; \mathrm{mp} 241{ }^{\circ} \mathrm{C}$ (dec); IR (Nujol mull): $v_{\max } / \mathrm{cm}^{-1} 2225 \mathrm{~m}(\mathrm{CN}), 2209 \mathrm{~m}(\mathrm{CN}), 1677 \mathrm{~m}(\mathrm{CO}), 1596 \mathrm{~s}, 1584 \mathrm{~s}$, $1529 \mathrm{~s} ; \delta_{\mathrm{H}}\left(300 \mathrm{MHz} ;\left(\mathrm{CD}_{3}\right)_{2} \mathrm{SO}\right) 13.60(1 \mathrm{H}, \mathrm{s}, \mathrm{NH}), 10.46(1 \mathrm{H}, \mathrm{s}$, $\mathrm{NH}), 8.75(1 \mathrm{H}, \mathrm{s}, 2-\mathrm{H}), 8.49(1 \mathrm{H}, \mathrm{d}, J 3.6 \mathrm{~Hz}, 7-\mathrm{H}), 8.24(2 \mathrm{H}, \mathrm{d}, J$ 8.7 Hz, Ar-H), 7.83 (2 H, d, J 8.7 Hz, Ar-H), 3.81 ( $3 \mathrm{H}, \mathrm{s}, \mathrm{COOMe})$. HRMS (FAB) $m / z$ (FAB) $346.1052\left((\mathrm{M}+\mathrm{H})^{+} . \mathrm{C}_{17} \mathrm{H}_{12} \mathrm{~N}_{7} \mathrm{O}_{2}\right.$ requires 346.1052). The mother liquor was concentrated to a viscous oil and addition of ethanol and diethyl ether led to a yellow solid, which was filtered and washed with diethyl ether. This product was identified as the 6-(1-amino-2,2-dicyanovinyl)-9-(4-cyanophenyl) purine 6j (0.03 g, $0.09 \mathrm{mmol}, 17 \%)$.

Method B. A solution of methylcyanoacetate $(0.05 \mathrm{~g}, 0.46 \mathrm{mmol})$ in dry acetonitrile $(5 \mathrm{~mL})$ was combined with a catalytic amount of DBU, at room temperature. 9-(4-Cyanophenyl)-6-(methoxyformimidoyl)purine $3 \mathbf{d}(0.12 \mathrm{~g}, 0.42 \mathrm{mmol})$ was added and the suspension was efficiently stirred at room temperature for $15 \mathrm{~h}$. The mixture was refluxed for 2 days and then allowed to stand at room temperature for another 2.5 days. A yellow-greenish solid was filtered, washed with diethyl ether and identified as the pyrimidopyrimidine 10a (0.06 g, $0.17 \mathrm{mmol}, 40 \%)$.

Method C. A solution of methylcyanoacetate $(0.42 \mathrm{~g}, 4.20 \mathrm{mmol})$ and dimethylaminopyridine $(0.60 \mathrm{~g}, 4.89 \mathrm{mmol})$ in DMF $(4 \mathrm{~mL})$ was combined with 9-(4-cyanophenyl)-6-(methoxyformimidoyl)purine $3 \mathbf{d}(0.23 \mathrm{~g}, 0.83 \mathrm{mmol})$ at room temperature. The white suspension was efficiently stirred at room temperature and after 2.5 days the pale yellow solid was filtered and washed with ethanol and diethyl ether, leading to $0.15 \mathrm{~g}$ of a mixture of pyrimido-pyrimidines 10a and 11 in a $1: 3$ ratio (by ${ }^{1} \mathrm{H}$ NMR). A second crop of solid was isolated after slow evaporation of the solvent. This product was identified as the pyrimido-pyrimidine 11 (0.03 g, $0.11 \mathrm{mmol}, 13 \%)$; mp $209{ }^{\circ} \mathrm{C}$ (dec); IR (Nujol mull): $v_{\max } / \mathrm{cm}^{-1} 2220 \mathrm{~m}(\mathrm{CN}), 1605 \mathrm{~s}$, $1585 \mathrm{~m}, 1557 \mathrm{~m}, 1532 \mathrm{~s} ; \delta_{\mathrm{H}}\left(300 \mathrm{MHz} ;\left(\mathrm{CD}_{3}\right)_{2} \mathrm{SO}\right) 10.67(1 \mathrm{H}, \mathrm{s}, \mathrm{NH})$, $8.93(1 \mathrm{H}, \mathrm{s}, 7-\mathrm{H}), 8.79(1 \mathrm{H}, \mathrm{s}, 2-\mathrm{H}), 8.31$ (2 H, d, $J 8.7 \mathrm{~Hz}, \mathrm{Ar}-\mathrm{H})$, $7.84(2 \mathrm{H}, \mathrm{d}, J 8.7 \mathrm{~Hz}, \mathrm{Ar}-\mathrm{H}), 4.14(3 \mathrm{H}, \mathrm{s}, \mathrm{OMe}) ; \delta_{\mathrm{C}}(75 \mathrm{MHz}$; $\left.\left(\mathrm{CD}_{3}\right)_{2} \mathrm{SO}\right) 165.9,156.7,155.8,153.8,142.9,134.7,133.9,132.9$, $121.5,119.2,105.3,55.0$. HRMS (FAB) $\mathrm{m} / \mathrm{z}$ (FAB) 279.098929 $\left((\mathrm{M}+\mathrm{H})^{+} . \mathrm{C}_{14} \mathrm{H}_{10} \mathrm{~N}_{6} \mathrm{O}\right.$ requires 279.099434).

\section{Reaction of 9-(4-methoxyphenyl)-6-(1-amino-2-cyano-2- methoxycarbonylvinyl)purine $6 \mathrm{~g}$ with methylcyanoacetate}

A solution of purine $6 \mathrm{~g}(0.02 \mathrm{~g}, 0.06 \mathrm{mmol})$ in DMF $(2 \mathrm{~mL})$ was combined with DMAP $(0.01 \mathrm{~g}, 0.08 \mathrm{mmol})$ and the mixture was stirred at room temperature. Addition of methylcyanoacetate $(0.05 \mathrm{~g}, 0.51 \mathrm{mmol})$ and stirring at room temperature for $5 \mathrm{~h}$ led to the formation of a solid suspension. After another $14 \mathrm{~h}$ at room temperature, the yellow solid was filtered and washed with ethanol. This product was identified as the pyrimido-pyrimidine 10b $(0.014 \mathrm{~g}, 0.04 \mathrm{mmol}, 70 \%)$; mp 264-266 ${ }^{\circ} \mathrm{C}$ (dec); (Found: $\mathrm{C}$, 58.16; H, 4.17; N, 23.75. Calc. for $\mathrm{C}_{17} \mathrm{H}_{14} \mathrm{~N}_{6} \mathrm{O}_{3}$ : C, 58.29; $\mathrm{H}, 4.00$; $\mathrm{N}, 24.00 \%$ ); IR (Nujol mull): $v_{\max } / \mathrm{cm}^{-1} 3348 \mathrm{~m}(\mathrm{NH}), 2207 \mathrm{~m}(\mathrm{CN})$, $1666 \mathrm{w}(\mathrm{CO}), 1604 \mathrm{~s}, 1576 \mathrm{~s}, 1584 \mathrm{~s}, 1552 \mathrm{~s} ; \delta_{\mathrm{H}}\left(300 \mathrm{MHz} ;\left(\mathrm{CD}_{3}\right)_{2} \mathrm{SO}\right)$ 13.52 (1 H, s, NH), 9.95 (1 H, s, NH), $8.53(1 \mathrm{H}, \mathrm{s}, 2-\mathrm{H}), 8.45(1 \mathrm{H}$, 
s, 7-H), $7.78(2 \mathrm{H}, \mathrm{d}, J 9.0 \mathrm{~Hz}, \mathrm{Ar}-\mathrm{H}), 6.96(2 \mathrm{H}, \mathrm{d}, J 9.0 \mathrm{~Hz}, \mathrm{Ar}-\mathrm{H})$ 3.77 (3 H, s, COOMe), 3.75 (3 H, s, OMe).

\section{Reaction of 9-methyl-6-(methoxyformimidoyl)purine 3 f with methylcyanoacetate}

A solution of methylcyanoacetate $(0.12 \mathrm{~g}, 1.17 \mathrm{mmol})$ in dichloromethane $(5 \mathrm{~mL})$ was combined with a catalytic amount of piperidinium acetate and the mixture was efficiently stirred at room temperature for $35 \mathrm{~min}$. Addition of 9-methyl-6-methoxyformimidoyl purine $3 \mathbf{f}(0.15 \mathrm{~g}, 0.78 \mathrm{mmol})$ led to a pale yellow solution, which was refluxed for 2 days. The solution was concentrated in the rotary evaporator and addition of acetonitrile, THF and diethyl ether led to a solid product, which was filtered and washed with THF and diethyl ether. The product was identified as the 6-(1-amino-2,2-dicyanovinyl)-9-(4-methoxyphenyl) purine 6k (0.15 g, $0.61 \mathrm{mmol}, 77 \%)$.

\section{Acknowledgements}

The authors gratefully acknowledge the financial support by the University of Minho and Fundação para a Ciência e Tecnologia (project PRAXIS/C/QUI/10101/1998).

\section{References}

1 (a) E. Ichikawa and K. Kato, Curr. Med. Chem., 2001, 8, 385; (b) S. Raic-Malic, M. Grdisa, K. Pavelic and M. Mintas, Eur. J. Med. Chem., 1999, 34, 405; (c) G. H. Hakimelahy, N. W. Mei, A. A. Moosavi-Movadehi, H. Davari, S. Hakimelahi, K. Y. King, J. R. Hwu and Y. S. Wen, J. Med. Chem., 2001, 44, 1749.
2 (a) B. Golankiewicz, T. Ostrowski, T. Goslinski, P. Januszczyk, J. Zeidler, D. Baranowski and E. de Clercq, J. Med. Chem., 2001, 44, 4284; (b) G. Y. Song, V. Paul, H. Choo, J. Morrey, R. W. Sidwell, R. F. Schinazi and C. K. Chu, J. Med. Chem., 2001, 44, 3985; (c) G. H. Hakimelahy, T. W. Ly, A. A. Moosavi-Movadehi, M. L. Jain, M. Zakerinia, H. Davari, H. C. Mei, T. Sambaiah, A. A. Moshfegh and S. Hakimelahi, J. Med. Chem., 2001, 44, 3710.

3 (a) P. Schoffski, T. Hagedorn, V. Grunwald, H. Paul, K. Merkle, R. Kowalski and A. Ganser, J. Cancer Clin. Oncol., 2000, 126, 41; (b) K. L. Seley, P. Janusszczyk，A. Hagos， L. Zhang and D. T. Dransfield, J. Med. Chem., 2000, 43, 4877.

4 N. Hamamichi and T. Miyasaka, J. Heterocyclic Chem., 1990, 27, 835.

5 N. Hamamichi and T. Miyasaka, J. Heterocyclic Chem., 1990, 27, 2011

6 Z. B. Waldhof, Pat. 1029696, 1966; Z. B. Waldhof, Chem. Abstr., 1966, 65, 5472 .

7 D. M. Brown and A. Ginner-Sorolla, J. Chem. Soc. (C), 1971, 128.

8 M. J. Alves, B. L. Booth, O. Kh. Al-Duaij, P. Eastwood, L. Nezhat, M. F. Proença and A. S. Ramos, J. Chem. Res. (S), 1993, 402; M. J. Alves， B. L. Booth，O. Kh. Al-Duaij, P. Eastwood, L. Nezhat, M. F. Proença and A. S. Ramos, J. Chem. Res. (M), 1993, 2701.

9 M. A. Carvalho, T. M. Esteves, M. F. Proença and B. L. Booth, Org. Biomol. Chem., 2004, 2, 1019

10 (a) B. L. Booth, R. D. Coster and M. F. Proença, Synthesis, 1988, 389; (b) M. J. Alves, B. L. Booth, M. A. Carvalho, R. G. Pritchard and M. F. Proenca, J. Heterocyclic Chem., 1997 739; (c) A. Al-Azmi， B. L. Booth， R. A. Carpenter, M. A. Carvalho, E. Marrelec, R. G. Pritchard and M. F. Proença, J. Chem. Soc., Perkin Trans 1,2001, 2532.

11 The Chemistry of Amidines and Imidates, ed. S. Patai and Z. Rappoport, John Wiley \& Sons, New York, 1991, vol. 2, p.p 448-452. 